\title{
Investigation of the Relationship Between Brent Oil and Cryptocurrencies During the COVID-19 Pandemic Period
}

\author{
Abdulkadir Kurt ${ }^{\mathrm{a}}$, Veysel Kula ${ }^{\mathrm{b}, *}$ \\ ${ }^{a}$ n MSc in International Trade and Finance Graduate, Afyon Kocatepe University \\ ${ }^{\mathrm{b}}$ Prof., Faculty of Economics and Administrative Sciences, Afyon Kocatepe University
}

\begin{tabular}{|c|c|}
\hline A B S T R A C T & A R T I C L E I N F O \\
\hline $\begin{array}{l}\text { The function of money plays an essential and indisputable role } \\
\text { in developing trade. Typically, banknotes and coins are usually } \\
\text { introduced by central authorities. However, Bitcoin, which } \\
\text { emerged after the } 2008 \text { crisis, was considered the original }\end{array}$ & $\begin{array}{l}\text { Keywords: } \\
\text { Bitcoin, Ethereum, Brent Oil, } \\
\text { Cryptocurrencies, Granger Causality Test, } \\
\text { COVID-19 }\end{array}$ \\
\hline $\begin{array}{l}\text { cryptocurrency and contributed to money in an unprecedented } \\
\text { dimension as it is the first decentralized peer-to-peer payment } \\
\text { network. Cryptocurrencies are in constant interaction and have } \\
\text { a casualty relationship, among other variables, with Brent Oil. } \\
\text { This study attempts to investigate the relationship between }\end{array}$ & $\begin{array}{l}\text { *Corresponding author: } \\
\text { kula@aku.edu.tr } \\
\text { (Veysel Kula) }\end{array}$ \\
\hline Bitcoin, Ethereum and Brent Oil price movements using 210 & Article history: \\
\hline daily data extractions between 10.12 .2019 and 01.10 .2020 , & Received : 05.03.2021 \\
\hline featuring the period of the start and spread of the COVID-19 & Revised : 11.04.2021 \\
\hline $\begin{array}{l}\text { pandemic. In this study, the casualty relationship among Brent } \\
\text { Oil, Bitcoin and Ethereum was examined with the Granger }\end{array}$ & Accepted : 09.05.2021 \\
\hline $\begin{array}{l}\text { Causality test. As a result of the study, a bidirectional casualty } \\
\text { relationship was determined between Brent Oil and Ethereum. } \\
\text { However, a one-way causality relationship was also found } \\
\text { between Brent Oil and Bitcoin. On the other hand, there is no } \\
\text { causality relationship between Ethereum and Bitcoin. }\end{array}$ & DOI:https://doi.org/10.51410/jcgirm.8.1.9 \\
\hline
\end{tabular}

\section{INTRODUCTION}

With the emergence of humanity, the need for consumption, production and trade (shopping) has also emerged. People's consumption and production predate trade, with the need for shopping arising over time. Although people first realized exchange transactions with barter, complexities led people to use a standard exchange variable. In history, animals, wheat and barley were used as a means of exchange for the first time, and then these products were replaced by precious metals such as silver, copper and iron. With the introduction of gold money, gold and coins became widespread in trade. Due to the security problems of its storage, gold and coins were abandoned, and leather money, the first documented type of banknote, was invented. With the development and globalization of the world, this type of money has left its place to paper money, which is lighter and more practical. However, with the acceleration of technology and trade, this development was also insufficient. As needs and habits changed over time, cash has started being replaced by digital currencies. Today, the last conception of money is crypto money. As Karadağ and Aymelek (2019) put forward, one of the most crucial turning points in the history of money was experienced during the 2008 financial crisis. With this crisis, 
global companies came to the point of bankruptcy. The cost incurred for rescuing these companies with the help of states has now been placed on people's shoulders. During this process, cryptocurrencies have emerged as traditional coins have somehow started losing their reputation.

On the other hand, petroleum is today amongst the most essential raw materials and has become of indispensable importance in commercial life. Apart from commercial uses, it is among the most valuable energy sources. In addition to being used as raw material, it is also used in production and logistics. Since it can affect other markets, movements in oil prices draw considerable attention. As indicated by K1liç (2017: 67), the most crucial feature that distinguishes Brent Petrol from other oils is its low production and logistics costs. However, oil moving westward from Europe, Africa and the Middle East is priced according to the Brent Oil price. Thanks to this feature, Brent Petrol is regarded as an international indicator.

In this study, the relationship between cryptocurrencies expressed as the money of the future, and Brent oil, which has experienced the worst price level in the last 30 years, will be examined. The selected period between 10.12.2019 and 01.10.2020 chosen for analysis enables us to reveal the price relationship for the period marked by the COVID-19 pandemic.

\section{LITERATURE REVIEW}

Explaining the relationship between oil prices and macroeconomic indicators has gained importance, especially since the 1972 and 1979 oil crises. In that regard, researches by Hamilton (1983) and Trehan (1986) appear to be among the first renowned studies, with the research by Papapetrou (2001) also being a frequently cited study in the literature. Hamilton (1983) and Papapetrou (2001) focused on the relationship between oil, unemployment and gross national product. On the other hand, Trehan (1986), followed by other researchers such as Fratzscher et al. (2014), Babatunde (2015), Arfaoui and Rejeb (2017), Delgado (2018), and Liu et al. (2020), focused on the interaction between exchange rates and oil.

Another section of research on oil (for example, Arfaoui and Rejeb, 2017; Yun and Yoon, 2019; Corbet et al., 2020b) focused on examining its relationship with stocks. Another set of studies on oil is about the effect of COVID-19 on the price of oil. For instance, Sansa (2020) found that oil prices were negatively affected by the number of COVID-19 cases and the COVID-19 outbreak.

There are frequently cited studies in the literature on oil within the context of Turkey. Some of these studies (Abdioğlu \& Değirmenci, 2014; Eyüboğlu \& Eyüboğlu, 2016; İşcan, 2010; Kapusuzoğlu, 2011) focused on measuring the relationship of oil prices with stock prices. Furthermore, another part of the researches probed the relationship between oil and BIST indices (Timur and Günay, 2019; Kirac1, 2020). Finally, another group of studies examined the relationship among COVID-19, gold and oil (Sarı and Kartal, 2020; Gülhan, 2020; Çevik et al., 2020). 
On the other hand, studies on cryptocurrencies have started to appear in the literature following the article by Satoshi Nakamoto titled "Bitcoin: A Peer-To-Peer Electronic Cash System" in 2008. Since then, cryptocurrencies have taken up their share in econometric studies alongside domestic and foreign currencies. Similar studies using exchange rates have been performed this time by using cryptocurrencies.

In general, a significant part of the studies regarding cryptocurrencies (Eswara, 2017; Miglietti et al., 2019; Yarovaya et al., 2020) focused on exchange rates. Another vital part of the studies on cryptocurrencies (Kostika and Laopodis, 2019; Maghyereh and Abdoh, 2021; Conlon et al., 2020; Lahmiri and Bekiros, 2020; Caferra and Vidal-Tomas, 2021; Kjaerland et al., 2018) examined the relationship between cryptocurrencies, stocks and stock market performance. Another brand of studies (for example, Burggraf et al., 2020; Ghorbel and Jeribi, 2020) probed the interaction between cryptocurrencies and fear indices. Some other studies, such as Corbet et al. (2020a), James et al. (2020) and Mnif et al. (2020), investigate the effect of COVID-19 on cryptocurrencies. Finally, there are researches on cryptocurrencies (for example, Derbali et al., 2020; Yin et al., 2021; Ghazani and Khosravi, 2020; Nunes, 2017; Ji et al., 2019) that have focused on oil and gold.

When it comes to the research in Turkey, an essential part of the studies on cryptocurrencies in Turkey (Yıldırım, 2018; Kamisli, 2019; Pirgaip et al., 2019; Aghalıbaylı, 2019; Gürsoy, Tunçel and Sayar, 2020; Gül,2020; Deniz and Teker, 2019; Deniz and Teker, 2020; Deniz, 2020) focused on the interaction between cryptocurrencies and gold. Another group of studies (Dirican and Canoz, 2017; Hamid and Talib, 2019; Erdas and Çağlar, 2018; Gürsoy, Tunçel and Sayar, 2020) examined the relationship between cryptocurrencies and indices. There are studies (for example, Ağan and Aydın, 2018; Özyeşil, 2019; Çakın, 2019; Dere, 2019; Aghalıbaylı, 2019 and Gül, 2020) focusing on cryptocurrencies and exchange rates. The relationship between cryptocurrencies and Brent oil has been the subject of a limited number of studies by Gül (2020), Deniz and Teker (2019), Deniz and Teker (2020), and Deniz (2020).

Using daily data between 7 August 2015 and 23 January 2020, Gül (2020) evaluated the effect of adding selected cryptocurrencies (Bitcoin, Ethereum, Ripple) into portfolios with several assets, including Brent oil. The study results revealed that with the addition of cryptocurrencies to portfolios, overall higher returns were obtained, and lower risk levels were achieved.

Deniz and Teker (2019), by using daily data between the period of 28.04.2013 and 23.07.2019, aimed at identifying the interaction between Bitcoin, Brent oil and gold. According to their results, gold and Brent oil prices do not substantially affect daily Bitcoin prices. In their later study and using a daily database between 3 April 2018 to 31 December 2019, Deniz and Teker (2020) included two more cryptocurrencies, namely Etherium and Ripple, together with Bitcoin in their analysis. The analysis revealed that only Bitcoin has a short term impact on gold prices. Furthermore, no causality was found between Ethereum, Ripple, gold and Brent oil.

In her Masters Dissertation, Deniz (2020), using the same period as Deniz and Teker (2020), but widening the scope of cryptocurrencies by employing seven types (Bitcoin, Ethereum, Ripple, Tether, Bitcoin Cash, Bitcoin S.V. and Litecoin), searched for the price relationship 
between gold, Brent oil and the selected seven cryptocurrencies with high market values. The same results were confirmed here, with only Bitcoin having a short term impact on gold prices.

As the novel virus in Wuhan, China, was discovered in December 2019, studies mentioned above by Deniz and Teker (2019), Deniz and Teker (2020) and Deniz (2020) do not cover the COVID-19 epidemic period in analyzing the interaction between cryptocurrencies and Brent oil. Therefore, in the current study, daily data between 10 December 2019 and 1 October 2020 were examined to explore the relationship between cryptocurrencies and Brent oil during the spreading stage of the pandemic. Furthermore, since both Bitcoin and Ethereum single themselves out in terms of market capitalization, they are the cryptocurrencies selected to be included in the analysis of the current study.

\section{DATA SOURCES AND RESEARCH METHODS}

While selecting the data for the analysis, the period between 10.12.2019 and 01.10.2020 was taken as a basis, imminently covering the date of 31.12.2019, when pneumonia cases of unknown cause were first reported by China (Budak and Korkmaz, 2020). Hence, the selected period features well the time when Covid-19 disease started to spread globally. Analysis was carried out using a total of 210 daily data extractions. The data for the three variables, Bitcoin, Ethereum, and Brent petroleum, used in the analysis were taken from the website www.tr.investing.com.

In the current study, as the first step, the Phillips-Perron and Augmented Dickey-Fuller unit root tests were conducted to see whether the series are stationary. As the series turned out to be nonstationary at the level, the same tests were then used on the logarithmically first differenced variables. Finally, as the series became stationary at the integrated level of 1, the Johansen cointegration test was used to decide whether there was a long-run relationship between the series. As for identifying the casualty relationship, the Granger causality test was chosen as it is amongst the widely used causality tests in the literature.

\section{RESULTS AND INTERPRETATION}

Prior to analyzing time series, the Phillips-Perron (P.P.) and Augmented Dickey-Fuller (ADF) unit root tests were conducted to see whether the series were stationary. As reported in the top part of Table.1, the levels of the series are nonstationary. 
Table 1: Unit Root Test Results

\begin{tabular}{|c|c|c|c|c|c|}
\hline \multirow{2}{*}{---------- } & \multirow{2}{*}{ Variables } & \multicolumn{2}{|c|}{ ADF } & \multicolumn{2}{|c|}{ PP } \\
\hline & & t-statistics & Probability & t-statistics & Probability \\
\hline \multirow{3}{*}{ Level } & Brent & -1.120071 & 0.9223 & -1.294625 & 0.8864 \\
\hline & Bitcoin & -2.444997 & 0.3553 & -2.396530 & 0.3803 \\
\hline & Ethereum & -2.144194 & 0.5177 & -2.144194 & 0.5177 \\
\hline \multirow{3}{*}{$\begin{array}{l}\text { Logarithmic } \\
\text { difference }\end{array}$} & Brent & -12.42934 & $0.0000^{*}$ & -12.45607 & $0.0000 *$ \\
\hline & Bitcoin & -17.85550 & $0.0000 *$ & -17.58353 & $0.0000^{*}$ \\
\hline & Ethereum & -17.58892 & $0.0000^{*}$ & -17.28879 & $0.0000^{*}$ \\
\hline
\end{tabular}

Then, the logarithmically first differenced series was created, and the analysis was repeated. As reported in the bottom part of Table.1, after taking their first differences, all series now became stationary, as they are integrated of order 1.

Consequently, the cointegration relationship is explored to see whether there is a long-run or equilibrium relationship between Brent oil and Cryptocurrencies. The Johansen Cointegration Test is run in this study, and the results are reported in Table.2.

Table 2: Johansen Cointegration Test

\begin{tabular}{|l|l|l|l|l|}
\hline & Eigenvalue & Trace statistic & 0.05 Critical Value & Probability \\
\hline Zero* & 0.240308 & 131.2328 & 24.27596 & 0.0001 \\
\hline At most $1^{*}$ & 0.203082 & 74.88998 & 12.32090 & 0.0000 \\
\hline At most $2^{*}$ & 0.12174 & 28.35423 & 4.129906 & 0.0000 \\
\hline
\end{tabular}

As appears in Table.2, both Trace statistics and Max-Eigen statistics were less than the critical value at the $5 \%$ significance level in three models, leading to the rejection of the null hypothesis of no causality between Brent oil and cryptocurrencies. The test, therefore, reveals the existence of three cointegration relationships between Brent oil and Cryptocurrencies. In other words, the variables move together in the long run. Therefore, the Granger Causality test was used as the next step to explore the (Granger) causality relationships between the variables. For this PAGE 141| Journal of Corporate Governance, Insurance, and Risk Management | 2021, VOL. 8, Series. 1 
purpose, the appropriate Vector Autoregression (VAR) model was established, and the maximum number of lags was determined as 3 . The test results are provided in Tables 3,4 , and 5.

Table 3: Dependent Variable: Brent oil

\begin{tabular}{|c|c|c|c|c|}
\hline Independent variables & Chi-sq & $\mathrm{df}$ & Probability & relation \\
\hline Bitcoin & 4.265841 & 3 & 0.2342 & none \\
\hline Ethereum & 8.011019 & 3 & 0.0458 & available \\
\hline ALL & 17.73848 & 6 & 0.0069 & significant \\
\hline
\end{tabular}

Before reporting the results of the Granger Causality tests, it should be noted that, as Brooks (2008) indicates, the word 'causality' is somewhat of a misnomer, for Granger-causality really means only a correlation between the current value of one variable and the past values of others; it does not mean that movements of one variable cause movements of another. Table 3 reports the model where Brent Petrol is picked as the dependent variable; A (Granger) causality relationship was found between Brent Petrol and Ethereum at the 5\% significance level. On the other hand, it appears that Bitcoin does not affect Brent Petrol. The model where Bitcoin is taken as the dependent variable is reported in Table 4.

Table 4: Dependent Variable: Bitcoin

\begin{tabular}{|c|c|c|c|c|}
\hline Independent variables & Chi-sq & df & Probability & Relation \\
\hline Brent & 19.23048 & 3 & 0.0002 & available \\
\hline Ethereum & 0.734533 & 3 & 0.8651 & none \\
\hline ALL & 19.52948 & 6 & 0.0034 & significant \\
\hline
\end{tabular}

As shown in Table.2, Brent Petrol (Granger) causes Bitcoin prices at the 5\% significance level. On the other hand, Ethereum does not (Granger) cause Bitcoin prices. Finally, in the last model reported in Table 5, Ethereum is used as the dependent variable. 
Table 5: Dependent Variable: Ethereum

\begin{tabular}{|c|c|c|c|c|}
\hline Independent variables & Chi-sq & df & Probability & Relation \\
\hline Brent & 14.34224 & 3 & 0.0025 & available \\
\hline Bitcoin & 5.685076 & 3 & 0.1280 & none \\
\hline ALL & 21.14453 & 6 & 0.0017 & significant \\
\hline
\end{tabular}

According to the results reported in the Table, Brent Petrol (Granger) causes Ethereum prices, whereas Bitcoin does (Granger) cause Ethereum.

The study's overall findings could be succinctly summarized as in Figure.1.

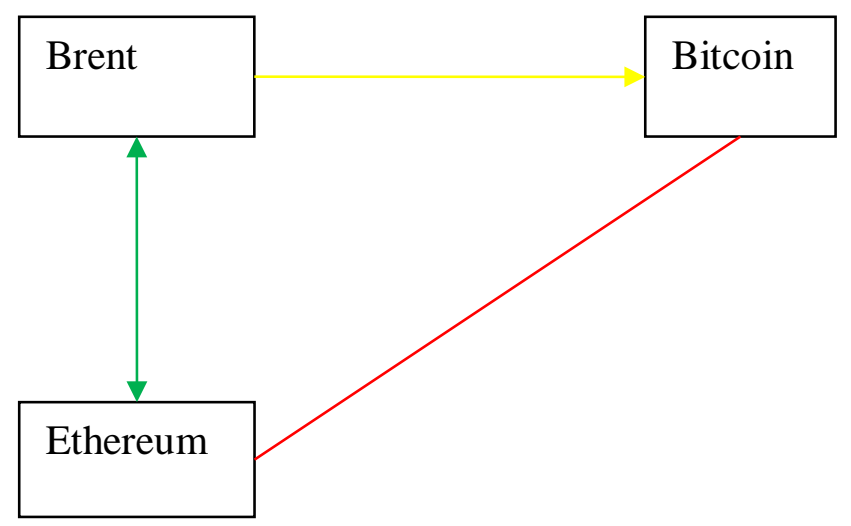

Figure 1: (Granger) Causality Flows

As seen from Figure 1, there is a bi-directional (Granger) causality between Brent Petrol and Ethereum during the Pandemic period. Moreover, (Granger) causality relationship between Brent Petrol and Bitcoin is one way, from Brent petrol to Bitcoin. Finally, Bitcoin and Ethereum are independent of each other, with no (Granger) causality.

\section{CONCLUSIONS}

The current research attempts to determine the relationship between Bitcoin, Ethereum and Brent Oil price movements during the pandemic. First, the VAR model was used to investigate the relationship between Brent oil, Bitcoin and Ethereum using 210 daily data from 20.12.2019 to 01.10 .2020 . Then, the direction of the relationship between the variables was determined by the Granger causality test. 
As discussed in the literature review, a limited number of studies are available exploring the causality between cryptocurrencies and Brent oil. The results of those studies indicated that Brent oil has no casuality relationship with Bitcoin (Deniz, 2020; Deniz and Teker, 2019; and Deniz and Teker, 2020) and Ethereum (Deniz, 2020; and Deniz and Teker, 2020). However, the findings of this analysis reveal that Brent Petrol has the power to (Granger) cause Bitcoin prices. Another finding of the current study is that Ethereum and Bitcoin prices move independently of each other as there is no (Granger) causality relationship between Ethereum and Bitcoin.

Finally, bidirectional (Granger) causality was found between Brent Petrol and Ethereum. Overall, those causality relationships sound relatively plausible. The global oil market is the most important world energy market because of oil's dominant role as an energy source (Ural, 2006). Therefore, movements in the Brent oil prices appearing to lead those of Bitcoin and Ethereum seem worthy of acceptance. On the other hand, of the two cryptocurrencies covered in the analysis, changes in Ethereum prices, not Bitcoin prices, precede changes in Brent oil prices. This finding seems surprising as Bitcoin has the most name recognition in the markets and has more than twice the market capitalization value of Ethereum. The fact that Ethereum has the potential to revolutionize finance and technology and the bullish sentiment among experts in the field appears to have only grown in 2020 for Ethereum (Divine, 2021) might explain the pioneering role Ethereum takes over in preceding the Brent oil price movements.

\section{Acknowledgement}

This article is produced from a dissertation of the same title presented by Abdulkadir Kurt under the supervision of Veysel Kula in part consideration for the degree of Master of Science in International Trade and Finance at Afyon Kocatepe University.

\section{REFERENCES}

Abdioğlu, Z. and Değirmenci, N. (2014). Petrol Fiyatları- Hisse Senedi Fiyatları İlişkisi: BİST Sektörel Analizi. Kafkas Üniversitesi İktisadi ve İdari Bilimler Fakültesi Dergisi, 5(8), $1-24$

Ağan, B. and Aydın, Ü. (2018), Kripto Para Birimlerinin Küresel Etkileri: Asimetrik

Nedensellik Analizi, Uluslararası Finans Sempozyumu, Mersin, ss 797-816

Aghalıbayl1, N. (2019). Bitcoin As a Cryptocurrency and Its Realionship With Gold, Crude

Oil and Euro Exchange Rate. (Yayınlanmamış Yüksek Lisans Tezi). Marmara

Üniversitesi, İstanbul.

Arfaoui, M. and Rejeb, A. B. (2017). Oil, Gold, U.S. Dollar and Stock Market

Interdependencies: A Global Analytical Insight. Emerald 26(3), 278-293 
Babatunde, M. A. (2015). Oil Price Shocks and Exchange Rate in Nigeria. Emerald, 9(1), 219

Brooks, C. (2008). Introductory Econometrics for Finance. Cambridge University Press, Second Edition.

Budak, F. and Korkmaz, Ş. (2020). COVID-19 Pandemi Sürecine Yönelik Genel Bir Değerlendirme: Türkiye Örneği. Sosyal Araştırmalar ve Yönetim Dergisi, (1), 62-79

Burggraf, T., Huynh, T. L. D., Rudolf, M., Wang, M. (2020). Do FEARS Drive Bitcoin? Emerald. 1940(5979), 1-30

Caferra, R. and Vidal-Tomas, D. (2021). Who Raised From the Abyss? A Comparison Between Cryptocurrency and Stock Market Dynamics During the COVID-19 Pandemic. Finance Research Letters. Xx(xx), 1-9

Çakın, M. (2019). Kripto Paralar: Bitcoin, Döviz Kurlarl ve Alternatif Paralar Arasındaki İlişkinin İncelenmesi. (Yayınlanmamış Yüksek Lisans Tezi). Dokuz Eylül Üniversitesi, İzmir.

Çevik, E., Yalçın, E. C., Özdemiryazgan, S. (2020). COVID-19 Pandemisinin Petrol ve Altın Fiyatları Üzerine Etkisi: Parametrik Olmayan Eşbütünleşme Sıra Testi. Gaziantep University Journal of Social Sciences, Special Issue, 633-646

Conlon, T., Corbet, S. and McGee, R. (2020). Are Cryptocurrencies a Safe Haven for Equity Markets? An İnternational Perspective from the COVID-19 Pandemic. Research in International Business and Finance, 54(2020), 1-10

Corbet, S., Hou, T. G., Hu, Y., Larkin, C., Oxley, L. (2020a). Any Port in a Storm: Cryptocurrency Safe-Havens During The COVID-19 Pandemic. Economics Letter, 194(1), 1-7

Corbet, S., Larkin, C., Lucey, B. (2020b), The Contagion Effects of the Covid-19 Pandemic: Evidence From Gold And Cryptocurrencies. Finance Research Letters, 35(1). 1-8

Delgado, N. A. B. (2018), The Relationship Between Oil Prices, the Stock Market and the Exchange Rate: Evidence From Mexico. North American Journal of Economics and Finance, 45, 266-275

Deniz, E. A. (2020). Finansal Piyasalarda Kripto Para Uygulamalart: Kripto Para Fiyatlarını Etkileyen Faktörler, Basılmamış Yüksek Lisans Tezi, Işık Üniversitesi Sosyal Bilimler Enstitüsü, İstanbul 2020

Deniz, E. A. and Teker, D. (2019). Determinants of Bitcoin Prices. PressAcademia (Say1 10), $17-21$ 
Deniz, E. A and Teker, D. (2020). Determinants of Cryptocurrency Market: An Analysis for Bitcoin, Ethereum and Ripple. International Journal of Business and Social Science, 11(11), 36-45

Derbali, A., Jamel, L., Ltaifa, M. B., Elnagar, A. K., Lamouchi, A. (2020), FED and ECB: Which is Informative in Determining the DCC Between Bitcoin and Energy Commodities?. Emerald, 4(1), 77-102

Dere, Y. (2019). Kripto Para Birimi Bitcoin İle Ekonomik Göstergeler Arasındaki İlişkinin Ekonometrik Bir Analizi. (Yayınlanmamış Yüksek Lisans Tezi). Dokuz Eylül Üniversitesi, İzmir.

Dirican, C. and Canoz, İ. (2017). The Cointegration Relationship Between Bitcoin Prices and Major World Stock Indices: An Analysis With ARDL Model Approach. Journal of Economics, Finance and Accounting, 4(4), 377-392

Divine, J. (2021). Bitcoin vs Ethereum: Which Is a Better Buy?. https://money.usnews.com/investing/cryptocurrency/articles/bitcoin-vs-ethereum-which-isa-better-buy

Erdas, M. L. and Çağlar, A. E. (2018). Analysis of the Relationships Between Bitcoin and Exchange Rate, Commodities and Global Index by Asymmetric Causality Test, Eastern Journal of European Studies, 9(2), 27-45

Eswara, M. (2017), Cryptocurrency Gyration and Bitcoin Volatility, International Journal of Business and Administration Research Review, 3(18), 187-195 http://ijbarr.com/downloads/1908201732.pdf

Eyüboğlu, K. and Eyüboğlu, S. (2016). Brent Petrol ve Havayolu Şirketlerinin Hisse Senedi Fiyatlarına Etkisi, Çukurova Üniversitesi IIIBF Dergisi, sayı 1(20). 39-53

Fratzscher, M., Schneider, D., and Robays, I. V. (2014). Oil Prices, Exchange Rates and Asset Prices. European Central Bank- SSRN. Ss. 1-47, https://papers.ssrn.com/sol3/papers.cfm?abstract_id=2277448

Ghazani, M. M. and Khosravi, R. (2020). Multifractal Detrended Cross-Correlation Analysis on Benchmark Cryptocurrencies and Crude Oil Prices. Physica A, 560(2020), 1-14

Ghorbel, A. and Jeribi, A. (2020). Investigating The Relationships Between Volatilities of Cryptocurrencies and Financial Assets. Decisions in Economics and Finance, 1-27, https://745e9234ede24d509e2ae15e4d48ef6be2b3b85c.vetisonline.com/article/10.1007/s1 0203-020-00312-9

Gül, Y. (2020). Kripto Paralar ve Portföy Çeşitlendirmesi. Dumlupınar Üniversitesi Sosyal Bilimler Dergisi, 65, 125-141 
Gülhan, Ü. (2020). Kovid-19 Pandemisinin Altın Fiyatlarınına Etkisi: ARDL Analizi. Atatürk Üniversitesi İktisadi ve İdari Bilimler Dergisi,34(3), 1111-1125

Gürsoy, S.,Tunçel, M. B. and Sayar, B. (2020). Koronavirüsün (Covid-19) Finansal Göstergeler Üzerine Etkileri. Ekonomi Maliye Işsletme Dergisi, 3(1). 20-32

Hamid, A. F. A. and Talib, A. A. (2019). A Note on Bitcoin's Price Volatilty. JurnalKeuangan dan Perbankan, 23(3),376-384

Hamilton, J. D. (1983). Oil and the Macroeconomy Since World War II. The Journal of Political Economy, 91(2), 228-248

https://tr.investing.com/crypto/currencies, (Erişim Tarihi: 25.04.2021)

İşcan, E. (2010). Petrol Fiyatının Hisse Senedi Piyasası Üzerindeki Etkisi. Maliye Dergisi, 1(158), 607-617

James, N., Menzies, M. , Chan, J. (2020). Changes to the Extreme and Erratic Behaviour of Cryptocurrencies During COVİD-19. Physica A, 565(2021), 1-19

Ji, Q. , Bouri, E., Roubaud, D. and Kristoufek, L. (2019). Information Interdepence Among Energy, Cryptocurrency and Major Commodity Markets. Energy Economics, 81(2019), 1042-1055

Kamisli, M. (2019). Cryptocurrency as an Investment Vehicle: The Asymmetric Relationships Between Bitcoin and Precious Metals. Blockchain Economics and Financial Market Innovation, 319-344, https://doi.org/10.1007/978-3-030-25275-5_16

Kapusuzoğlu, A. (2011). Relationships Between Oil Prices and Stock Market: An Empirical Analysis from Istanbul Stock Exchange (ISE). International Journal of Economics and Finance, 3(6), 99-106

Karadağ, D. (Edt.) Aymelek, Ü.O. (Yöneten). (2019). Paranın Yeniden Keşfi: Bitcoin. [Belgesel]. Türkiye: 140journos, https:/www.youtube.com/watch?v=gnclsLp_NDU Kılıç, N. Ö. (2017). Petrol Fiyatları ve İktisadi Büyüme: OECD Ülkeleri Üzerine Bir Analiz. (Yayınlanmamış Doktora Tezi). Nevşehir Hacı Bektaş Veli Üniversitesi, Nevşehir Kiracı, K. (2020). BİST Ulaştırma Endeksi ile Dolar Endeksi ve Petrol Fiyatları Arasındaki İlişkinin Ampirik Olarak Analizi. Finansal Araştırmalar ve Çalışmalar Dergisi, 12(22), 180-189

Kjaerland, F., Khazal, A., Krogstad, E. A., Nordstorm, F. B. G. And Oust, A. (2018). An Analysis of Bitcoin's Price Dynamics. Risk and Financial Management. 11(63), 1-18 Kostika, E. and Laopodis, N. T. (2019). Dynamic Linkages Among Cryptocurrencies, Exchanges Rates and Global Equity Markets, Emerald, 1086(7376), 243-265 
Lahmiri, S. and Bekiros, S. (2020). The Impact of COVID-19 Pandemic Upon Stability and Sequential Irregularity of Equity and Cryptocurrency Markets. Chaos, Solitons and Fractals. 138 (2020), 1-6

Liu, Y., Failler, P., Peng, J. and Zheng, Y. (2020). Time-Varying Relationship Between Crude Oil Price and Exchange Rate in the Context of Structural Breaks. Energies, 13(2395), 1-17

Maghyereh, A. and Abdoh, H. (2021). Time-Frequency Quantile Dependence Between Bitcoin and Global Equity Markets. North American Journal of Economics and Finance. 56(2021), 1-11

Miglietti, C., Kubosova, Z. and Skulanova, N. N. (2019). Bitcoin, Litecoin and The Euro: An Annualized Volatility Analysis. Emerald, 37(2), 1-14

Mnif, E., Jarboui, A. and Mouakhar, K. (2020). How The Cryptocurrency Market Has Performed During COVID-19? A Multifractal Analysis. Finance Research Letters, 36(2020), 1-15

Nakamoto, S. (2008). Bitcoin: A Peer to Peer Electronic Cash System. 13 Aralık 2020, https://www.bitcoin.com/bitcoin.pdf

Nunes, B. S. R. (2017), Virtual Currency: A Cointegration Analysis Between Bitcoin Prices and Economic and Financial Data. Lisbon: ISCTE-IUL 2017, Master Thesis, https://repositorio.iscteiul.pt/bitstream/10071/16078/1/barbara_rosa_nunes_diss_mestrado.pdf

Özyeşil, M. (2019). A Research on İnteraction Between Bitcoin and Foreign Exchange Rates. Journal of Economics, Finance and Accounting,6(1), 55-62

Papapetrou, E. (2001). Oil Price Shocks, Stock Market, Economic Activity And Employment in Greece, 23(5), 511-532

Pirgaip, B., Dinçergök, B. and Haşlak, Ş. (2019). Bitcoin Market Price Analysis and an Empirical Comparison with Main Currencies, Commodities, Securities and Altcoins. Blockchain Economics and Financial Market Innovation, 141-166, https://doi.org/10.1007/978-3-030-25275-5_8

Sansa, N. A. (2020). Analysis For The Impact Of The Covid-19 To The Petrol Price In China. 10 January 2020 from https://papers.ssrn.com/sol3/papers.cfm?abstract_id=3547413

Sarı, S. S. and Kartal, T. (2020). COVID-19 Salgınının Altın Fiyatları, Petrol Fiyatları ve VIX Endeksi ile Arasındaki İlişki. Erzincan Üniversitesi Sosyal Bilimler Enstitüsü Dergisi, 13(1). 93-109

Timur, E. and Günay, B. (2019). Petrol Fiyatları ile Pay Senetleri Arasındaki İlişkinin Ekonometrik Analizi. Social Sciences Studies Journal(SSSjournal),5(44), 5204-5211 
Trehan, B. (1986). Oil Prices, Exchanges Rates and U.S Economy: An Empirical Investigation. Economic Review, 4, 25-43

Ural, M. (2006). The Impact Of The Global Financial Crisis On Crude Oil Price Volatility. Yönetim ve Ekonomi Araştırmaları Dergisi; 14(2), , 25-43 Doi: http://dx.doi.org/10.11611/JMER810

Yarovaya, L., Matkovskyy, R. and Jalan, A. (2020). The Effects of a "Black Swan" Event (COVID-19) on Herding Behavior in Cryptocurrency Markets: Evidence from Cryptocurrency USD, EUR, JPY and KRW Markets. SSRN, https://papers.ssrn.com/sol3/papers.cfm?abstract_id=3586511

Yıldırım, H. (2018). Günlük Bitcoin İle Altın Fiyatları Arasındaki İlişkinin Test Edilmesi: 2012-2013 Yılları arasında Johansen Eşbütünleşme Testi. Insan ve Toplum Bilimleri Araştırma Dergisi,7(4), 2328-2243. http://www.itobiad.com/tr/

Yin, L., Nie, J. and Han, L. (2021). Understanding Cryptocurrency Volatility: The Role of Oil Markets Shocks. International Review of Economics \&Finance, 72(1), 233-252

Yun, X. and Yoon, S. M. (2019). Impact of Oil Price Change on Airline's Stock Price and Volatility: Evidence from China and South Korea, Energy Economics, 78, 668-679 